\title{
PENINGKATAN HASIL BELAJAR SISWA MELALUI METODE THINK PAIR PAIR SHARE DALAM GERAK MELINGKAR KELAS X MADRASAH ALIYAH NEGERI 2 PONTIANAK.
}

\author{
Suminem \\ MAN 2 Pontianak \\ Email:mmsum311@yahoo.co.id
}

\begin{abstract}
In the first cycle implementing cooperative learning TPS the students' mastery is as high as $18 \%$ of 33 students, the second cycle there is an increase to $48.48 \%$. Because they have not reached minimal passing grade, the cycle is continued to the third cycle with the achievement grade $93.93 \%$ which is more than expectation. Therefore, the application of cooperative to study aims to improve students' mastery of learning outcomes in circular motion. The study was conducted on the class XF MAN 2 in even semester, using cooperative learning methods TPS with the helping of peer tutors. The researching forms an action research with 3 cycles. The results showed that polling method with the help of peer tutors can improve student learning outcomes in the thoroughness of the material optical instruments.
\end{abstract}

Keywords: Cooperative polling, peer tutoring assistance.

Usaha untuk meningkatkan mutu pendidikan di Indonasia, antara lain melalui pelatihan serta kualitas guru, pengadaan buku dan alat pelajaran, perbaikan sarana dan prasarana pendidikan lain, peningkatan mutu manajemen sekolah, Namun demikian, berbagai indikator mutu pendidikan belum menunjukkan peningkatan yang memadai. Upaya peningkatan kualitas pendidikan di tempat mengajar tidak pernah berhenti. Berbagai terobosan baru terus dilakukan oleh pemerintah melalui Depdiknas dan Kementerian Agama. Penjelasan dan pemeragaan semata tidak akan membuahkan hasil belajar yang langgeng. (Daroeso, 1986:20): "Belajar adalah suatu proses usaha yang dilakukan untuk memperoleh perubahan tingkah laku yang baru secara keseluruhan, sebagai pengalamannya sendiri dalam intraksi dengan lingkungannya yaitu dengan, mendengar, melihat, pertanyaan orang lain. Bukan Cuma itu, siswa perlu "mengerjakannya", yakni menggambarkan sesuatu dengan cara mereka sendiri, menunjukkan contohnya, mencoba mempraktekkan keterampilan, dan mengerjakan tugas yang menuntut pengetahuan yang telah atau harus mereka dapatkan. Driver and Bell (1986) dalam Leo Sutrisno (1994) mendefinisikan belajar adalah suatu proses aktif menyusun makna melalui setiap interaktif dengan lingkungan, dengan membangun hubungan antara konsepsi yang telah dimiliki dengan fenomena yang sedang dipelajari. Oleh karena itu, pemilihan model pembelajaran tutor sebaya sebagai strategi pem- 
belajaran akan sangat membantu siswa di dalam mengajarkan materi kepada teman-temannya.

Dengan menyadari gejala-gejala atau kenyataan tersebut, maka dalam penelitian ini mengambil judul “ Implementasi pembelajaran kooperatip TPS dengan bantuan tutor sebaya untuk meningkatkan hasil belajar fisika siswa Madrasah Aliyah Negeri 2 Pontianak". (Ibrahim, 2000:7) Pembelajaran kooperatif ini dikembangkan untuk mencapai hasil belajar akademik yaitu untuk meningkatkan ketuntasan hasil belajar fisika siswa kelas X semester genap.

\section{Metode}

Penelitian ini dilaksanakan di kelas X F Madrasah Aliyah Negeri 2 Pontianak pada semester genap tahun pelajaran 2011/2012. Subjek penelitian tindakan kelas ini sebanyak 33 siswa yang terdiri dari 17 siswa perempuan dan 16 siswa laki-laki. Alur dalam penelitian tindakan kelas menggunakan model pembelajaran kooperatif yang dikembangkan untuk mencapai setidaktidaknya tiga tujuan penting pembelajaran, yaitu hasil belajar akademik, penerimaan terhadap keragaman, dan pengembangan keterampilan social (Ibrahim, dkk, 2000:7)

Menurut Slavin (1997) pembelajaran kooperatif merupakan model pembelajaran yang membagi siswa dalam kelompok yang memiliki kemampuan heterogen. Peserta didik bekerja bersama dalam kelompok kecil dan saling membantu dalam belajar. (Anang Heriawan, 2012:5)
Data diperoleh dari aktivitas belajar siswa dan keterlaksanaan proses pembelajaran oleh guru. Tehnik yang digunakan dalam tindakan adalah tehnik Think-Pair-Shere yaitu: dengan cara ini siswa diberi pertanyaan atau soal untuk dipikirkan sendiri kurang lebih 2-3 manit.(Think) Kemudian siswa diminta untuk mendiskusikan jawaban atau pendapatnya dengan teman yang duduk didekatnya(Pair). Setelah itu pengajar dapat menunjuk satu atau lebih siswa untuk menyampaikan pendapatnya atas pertanyaan atau soal itu bagi seluruh kelas (Shere).(Anang Heriawan, 2012:173).

Teknik analisis data pada penelitian tindakan kelas ini menggunakan analisis kualitatif yang terdiri atas tiga alur kegiatan yaitu reduksi data, penyajian data, penarikan kesimpulan dan verivikasi data. Indikator kerja penelitian tindakan kelas ini pada ranah pengetahuan ditentukan besarnya kreteria ketuntasa minimal yaitu skor 60 dengan jumlah 33 siswa yang tuntas sebesar 93,93\% . aktivitas siswa pada akhir siklus sebesar 93,93\%.

\section{Hasil dan Pembahasan}

\section{A. Siklus I}

Alat pengumpul data berupa instrumen. Soal uraian sehingga data yang diperlukan dalam penelitian tindakan kelas dapat diperoleh melalui observasi pengolahan belajar yang aktif dan tes formatif. Nilai tes dalam bentuk tabel I sebagai berikut Data penelitian yang diperoleh berupa hasil uji coba item butir soal, data observasi berupa pengamatan pengelolaan belajar aktif, pengamatan aktivitas siswa, guru pada akhir pembelajaran, dan data tes 
formatif siswa pada setiap siklus. Validitas

Soal Valid dan Tidak Valid Tes yang terdiri soal valid ada 5 yaitu : no.

1,4,7,9 dan 10. soal tidak valid ada 5yaitu: no. 2,3,5,6,dan 8 .

Dari hasil perhitungan diperoleh koefisien reliabilitas $r_{11}$ sebesar 0,554 . Skor ini lebih besar dari skor $r$ product moment. Untuk jumlah siswa $(\mathrm{N}=32$ ) dengan $\mathrm{r}(95 \%)=0,404$. Jadi soal tes yang digunakan telah memenuhi syarat reliabilitas.

Taraf Kesukaran (P)

Taraf kesukaran digunakan untuk mengetahui tingkat kesukaran soal.
Hasil analisis menunjukkan dari 10 soal yang diuji terdapat:

1. 4 soal mudah

2. 4 soal sedang

3. 2 soal sukar

Analisis daya pembeda dilakukan untuk mengetahui kemampuan soal dalam membedakan siswa yang berkemampuan tinggi dengan siswa yang berkemampuan rendah. Dari hasil analisis daya pembeda diperoleh soal yang berkriteria jelek sebanyak 4 soal, berkriteria cukup 4 soal, berkriteria baik 2 soal. Dengan demikian soal-soal tes yang digunakan telah memenuhi syara-syarat validitas, reliabilitas, taraf kesukaran, dan daya pembeda

Tabel 1. Nilai Tes Essay Siklus I.

\begin{tabular}{|c|c|c|c|c|c|c|c|}
\hline \multirow{2}{*}{$\begin{array}{c}\text { No. } \\
\text { Urut }\end{array}$} & \multirow{2}{*}{ Nilai } & \multicolumn{2}{|c|}{ Keterangan } & \multirow{2}{*}{$\begin{array}{c}\text { No. } \\
\text { Urut }\end{array}$} & \multirow{2}{*}{ Nilai } & \multicolumn{2}{|c|}{ Keterangan } \\
\hline & & $\mathbf{T}$ & TT & & & $\mathbf{T}$ & TT \\
\hline 1 & 10 & & $\mathrm{~V}$ & 18 & 40 & & $\mathrm{v}$ \\
\hline 2 & 20 & & $\mathrm{~V}$ & 19 & 40 & & $\mathrm{v}$ \\
\hline 3 & 60 & $\mathrm{v}$ & & 20 & 40 & & $\mathrm{v}$ \\
\hline 4 & 70 & $\mathrm{~V}$ & & 21 & 40 & & $\mathrm{v}$ \\
\hline 5 & 80 & $\mathrm{~V}$ & & 22 & 50 & & $\mathrm{~V}$ \\
\hline 6 & 30 & & V & 23 & 20 & & $\mathrm{~V}$ \\
\hline 7 & 30 & & $\mathrm{~V}$ & 24 & 70 & $\mathrm{~V}$ & \\
\hline 8 & 40 & & $\mathrm{~V}$ & 25 & 70 & $\mathrm{v}$ & \\
\hline 9 & 50 & & V & 26 & 40 & & $\mathrm{~V}$ \\
\hline 10 & 30 & & $\mathrm{~V}$ & 27 & 20 & & $\mathrm{~V}$ \\
\hline 11 & 40 & & $\mathrm{~V}$ & 28 & 20 & & $\mathrm{~V}$ \\
\hline 12 & 20 & & V & 29 & 50 & & $\mathrm{v}$ \\
\hline 13 & 10 & & $\mathrm{~V}$ & 30 & 60 & $\mathrm{~V}$ & \\
\hline 14 & 20 & & $\mathrm{~V}$ & 31 & 30 & & $\mathrm{~V}$ \\
\hline 15 & 20 & & V & 32 & 20 & & $\mathrm{~V}$ \\
\hline 16 & 20 & & $\mathrm{~V}$ & 33 & 40 & & $\mathrm{~V}$ \\
\hline 17 & 20 & & $\mathrm{~V}$ & & & & \\
\hline$\underset{\mathrm{h}}{\text { Jumla }}$ & 570 & 3 & 14 & $\begin{array}{c}\text { Jumla } \\
\mathrm{h}\end{array}$ & 610 & 3 & 13 \\
\hline \multicolumn{8}{|c|}{$\begin{array}{l}\text { Jumlah Skor } 1180 \\
\text { Jumlah Skor Mask. Ideal } 1980 \\
\text { \% Skor Tercapai 35,75 }\end{array}$} \\
\hline
\end{tabular}


4 Jurnal Pendidikan Matematika dan IPA Vol. 5. No. 2. Juli 2014: 1-8

\begin{tabular}{clcc}
\hline No & \multicolumn{1}{c}{ Uraian } & Hasil Siklus I \\
\hline 1 & Nilai rata-rata tes essay & 35,75 \\
2 & Jumlah siswa yang tuntas & 6 \\
3 & belajar & $18,18 \%$ \\
& Persentase ketuntasan belajar & \\
\hline
\end{tabular}

Dari Tabel 2 diijelaskan bahwa dengan menerapkan metode kooperatif TPS dengan bantuan tutor sebaya diperoleh nilai rata-rata siswa adalah $18,18 \%$ dan ketuntasan belajar mencapai skor 60 sebanyak 6 siswa dari 33 siswa sudah tuntas belajar. Hasil tersebut menunjukkan bahwa pada siklus I secara klasikal siswa belum tuntas belajar, karena siswa yang memperoleh nilai $\geq 60$ hanya sebesar $18,18 \%$ lebih kecil dari persentase ketuntasan yang dikehendaki yaitu sebesar $85 \%$. Hal ini disebabkan siswa masih banyak kesulitan dengan motode pembelajaran yang baru diterapkan.

\section{B. Siklus II}

Pada siklus 2 ini hampir sama pada siklus I yang membedakan adalah waktu. Adapun hasil pada siklus 2 disajikan dalam bentuk tabel sebagai berikut:

Tabel 3. Nilai Tes Essay Siklus II.

\begin{tabular}{|c|c|c|c|c|c|c|c|}
\hline \multirow{2}{*}{$\begin{array}{l}\text { No. } \\
\text { Urut }\end{array}$} & \multirow{2}{*}{ Nilai } & \multicolumn{2}{|c|}{ Keterangan } & \multirow{2}{*}{$\begin{array}{l}\text { No. } \\
\text { Urut }\end{array}$} & \multirow{2}{*}{ Nilai } & \multicolumn{2}{|c|}{ Keterangan } \\
\hline & & $\mathbf{T}$ & TT & & & $\mathbf{T}$ & TT \\
\hline 1 & 10 & & $\mathrm{~V}$ & 18 & 80 & $\mathrm{~V}$ & \\
\hline 2 & 20 & & $\mathrm{~V}$ & 19 & 70 & $\mathrm{~V}$ & \\
\hline 3 & 60 & $\mathrm{~V}$ & & 20 & 80 & $\mathrm{~V}$ & \\
\hline 4 & 70 & $\mathrm{~V}$ & & 21 & 70 & $\mathrm{~V}$ & \\
\hline 5 & 80 & $\mathrm{~V}$ & & 22 & 70 & $\mathrm{v}$ & \\
\hline 6 & 30 & & $\mathrm{~V}$ & 23 & 20 & & $\mathrm{~V}$ \\
\hline 7 & 30 & & $\mathrm{~V}$ & 24 & 70 & $\mathrm{~V}$ & \\
\hline 8 & 40 & & $\mathrm{~V}$ & 25 & 70 & $\mathrm{~V}$ & \\
\hline 9 & 70 & $\mathrm{~V}$ & & 26 & 80 & $\mathrm{~V}$ & \\
\hline 10 & 30 & & $\mathrm{~V}$ & 27 & 20 & & $\mathrm{~V}$ \\
\hline 11 & 80 & $\mathrm{v}$ & & 28 & 20 & & $\mathrm{~V}$ \\
\hline 12 & 20 & & $\mathrm{~V}$ & 29 & 70 & $\mathrm{v}$ & \\
\hline 13 & 10 & & $\mathrm{~V}$ & 30 & 60 & $\mathrm{v}$ & \\
\hline 14 & 20 & & $\mathrm{~V}$ & 31 & 30 & & $\mathrm{~V}$ \\
\hline 15 & 20 & & $\mathrm{~V}$ & 32 & 20 & & $\mathrm{~V}$ \\
\hline 16 & 20 & & $\mathrm{~V}$ & 33 & 90 & $\mathrm{~V}$ & \\
\hline 17 & 20 & & $\mathrm{~V}$ & & & & \\
\hline $\begin{array}{c}\text { Juml } \\
\text { ah }\end{array}$ & 630 & 5 & 12 & $\begin{array}{c}\text { Juml } \\
\text { ah }\end{array}$ & 930 & 11 & 5 \\
\hline Jumla & & & & & & & \\
\hline
\end{tabular}




\begin{tabular}{lllllll}
\hline No. & \multirow{2}{*}{ Nilai } & \multicolumn{2}{c}{ Keterangan } & \multirow{2}{*}{ No. } & \multirow{2}{*}{ Nilai } & \multicolumn{2}{c}{ Keterangan } \\
Urut & T & TT & Urut & & T & TT \\
\hline Jumlah Skor Mask. Ideal 1980 & & & & \\
\% Skor Tercapai 70,83 & & & & \\
\hline
\end{tabular}

Tabel .4. Hasil Tes Essay pada Siklus II

\begin{tabular}{llc}
\hline No & \multicolumn{1}{c}{ Uraian } & Hasil Siklus II \\
\hline 1 & Nilai rata-rata tes Essay & 50 \\
2 & Jumlah siswa yang tuntas belajar Per: & 16 \\
3 & tase ketuntasan belajar & $48,48 \%$ \\
\hline
\end{tabular}

Dari tabel di atas diperoleh nilai ratarata prestasi belajar siswa adalah klasikal telah mengalami peningkatan sedikit lebih baik dari siklus I. Adanya peningkatan hasil 50.00 dan ketuntasan belajar mencapai 48,48 \% atau ada 16 siswa dari 33 siswa sudah tuntas belajar. Hasil ini menunjukkan bahwa pada siklus II ini ketuntasan belajar secara belajar siswa.

C. Siklus III

Berikut adalah siklus yang ke 3 menunjukkan hasil yang sesuai harapan sebagai berikut:

Tabel 5. Nilai Tes Essay Siklus III.

\begin{tabular}{|c|c|c|c|c|c|c|c|}
\hline \multirow{2}{*}{ No. Urut } & \multirow{2}{*}{ Nilai } & \multicolumn{2}{|c|}{ Keterangan } & \multirow{2}{*}{$\begin{array}{c}\text { No. } \\
\text { Urut }\end{array}$} & \multirow{2}{*}{ Nilai } & \multicolumn{2}{|c|}{ Keterangan } \\
\hline & & $\mathbf{T}$ & TT & & & $\mathbf{T}$ & TT \\
\hline 1 & 30 & & $\mathrm{~V}$ & 18 & 80 & $\mathrm{~V}$ & \\
\hline 2 & 60 & $\mathrm{v}$ & & 19 & 70 & $\overline{\mathrm{V}}$ & \\
\hline 3 & 60 & $\mathrm{~V}$ & & 20 & 80 & $\mathrm{v}$ & \\
\hline 4 & 70 & $\mathrm{~V}$ & & 21 & 70 & $\overline{\mathrm{V}}$ & \\
\hline 5 & 80 & $\mathrm{v}$ & & 22 & 70 & $\mathrm{~V}$ & \\
\hline 6 & 70 & $\mathrm{~V}$ & & 23 & 60 & $\mathrm{v}$ & \\
\hline 7 & 80 & $\mathrm{v}$ & & 24 & 70 & $\mathrm{~V}$ & \\
\hline 8 & 90 & $\mathrm{v}$ & & 25 & 70 & $\mathrm{v}$ & \\
\hline 9 & 70 & & & 26 & 80 & $\mathrm{~V}$ & \\
\hline 10 & 80 & $\mathrm{v}$ & & 27 & 90 & $\mathrm{v}$ & \\
\hline 11 & 80 & $\mathrm{v}$ & & 28 & 60 & $\mathrm{v}$ & \\
\hline 12 & 90 & $\mathrm{v}$ & & 29 & 70 & $\mathrm{v}$ & \\
\hline 13 & 30 & & V & 30 & 60 & $\mathrm{v}$ & \\
\hline 14 & 60 & $\mathrm{v}$ & & 31 & 70 & $\mathrm{v}$ & \\
\hline 15 & 80 & $\mathrm{v}$ & & 32 & 80 & $\mathrm{v}$ & \\
\hline 16 & 80 & $\mathrm{v}$ & & 33 & 90 & $\mathrm{v}$ & \\
\hline 17 & 70 & $\mathrm{~V}$ & & & & & \\
\hline Jum lah & 1180 & 15 & 2 & $\begin{array}{l}\text { Jum } \\
\text { lah }\end{array}$ & 1170 & $\overline{16}$ & 0 \\
\hline
\end{tabular}

Jumlah Skor 2350

Jumlah Skor Mask. Ideal 1980

$\%$ Skor Tercapai 71,21 
6 Jurnal Pendidikan Matematika dan IPA Vol. 5. No. 2. Juli 2013: 1-8

Tabel 6. Hasil Tes Essay Siswa Siklus III.

\begin{tabular}{clc}
\hline No & \multicolumn{1}{c}{ Uraian } & Hasil Siklus III \\
\hline 1 & Nilai rata-rata tes Essay & 71,21 \\
2 & Jumlah siswa yang & 31 \\
3 & tuntas belajar & $93,93 \%$ \\
& $\begin{array}{l}\text { Persentase ketuntasan } \\
\text { belajar }\end{array}$ \\
\hline
\end{tabular}

Berdasarkan tabel diatas diperoleh nilai rata-rata tes formatif sebesar 71,.21 dan dari 33 siswa yang telah tuntas sebanyak 31 siswa dan 2 siswa belum mencapai ketuntasan belajar. Maka secara klasikal ketuntasan belajar yang telah tercapai sebesar 93,93\% (termasuk kategori tuntas). Hasil pada siklus III ini mengalami peningkatan lebih baik dari siklus II. Adanya peningkatan hasil belajar pada siklus III ini dipengaruhi oleh adanya kerjasama antar siswa.

Data penelitian yang diperoleh berupa hasil uji coba item butir soal, data observasi berupa pengamatan pengelolaan belajar aktif dan pengamatan aktivitas siswa dan guru pada akhir pembelajaran, dan data tes formatif siswa pada setiap siklus. Data hasil uji coba item butir soal digunakan untuk mendapatkan tes yang betul-betul mewakili apa yang diinginkan. Data ini selanjutnya dianalisis tingkat validitas, reliabilitas, taraf kesukaran, dan daya pembeda. Data lembar observasi diambil dari dua pengamatan yaitu data pengamatan pengelolaan belajar aktif yang digunakan untuk mengetahui pengaruh penerapan metode kooperatif Think Pair Shere dengan bantuan tutor sebaya dalam meningkatkan ketuntasan hasil belajar fisika siswa dan data pengamatan aktivitas siswa dan guru. Data tes formatif untuk mengetahui peningkatan ketuntasan hasil belajar fisika siswa setelah diterapkan metode kooperatif Think Pair Shere dengan bantuan tutor sebaya.

1. Ketuntasan Hasil belajar Siswa

Melalui hasil peneilitian ini menunjukkan bahwa metode kooperatif Think Pair Shere dengan bantuan tutor sebaya memiliki dampak positif dalam meningkatkan daya ingat siswa. Hal ini dapat dilihat dari semakin mantapnya pemahaman dan penguasaan siswa terhadap materi yang telah disampaikan guru selama ini (ketuntasan belajar meningkat dari sklus I, II, dan III) yaitu masing-masing 66,67\%, $75,00 \%$, dan $87,50 \%$. Pada siklus III ketuntasan belajar siswa secara klasikal telah tercapai.

2. Kemampuan Guru dalam Mengelola Pembelajaran

Berdasarkan analisis data, diperoleh aktivitas siswa dalam proses metode kooperatif TPS dengan bantuan tutor sebaya dalam setiap siklus mengalami 
peningkatan. Hal ini berdampak positif terhadap proses mengingat kembali materi pelajaran yang telah diterima selama ini, yaitu dapat ditunjukkan dengan meningkatnya nilai rata-rata siswa pada setiap siklus yang terus mengalami peningkatan.

3. Aktivitas Guru dan Siswa Dalam Pembelajaran

Berdasarkan analisis data, diperoleh aktivitas siswa dalam proses pembelajaran Fisika metode kooperatif Think Pair Share dengan bantuan tutor sebaya yang paling dominan adalah mendengarkan/ memperhatikan penjelasan guru, dan diskusi antar siswa/ antara siswa dengan guru. Jadi dapat dikatakan bahwa aktivitas siswa dapat dikategorikan aktif.

Sedangkan untuk aktivitas guru selama pembelajaran telah melaksanakan langkah-langkah belajar aktif dengan baik. Hal ini terlihat dari aktivitas guru yang muncul, di antaranya aktivitas membimbing dan mengamati siswa dalam mengerjakan kegiatan, menjelaskan, memberi umpan balik/evaluasi/tanya jawab dengan prosentase untuk aktivitas di atas cukup besar.

\section{Simpulan dan Saran}

Dari hasil kegiatan pembelajaran yang telah dilakukan selama tiga siklus, dan berdasarkan seluruh pembahasan serta analisis yang telah dilakukan dapat disimpulkan sebagai berikut:

1. Sebelum menerapkan metode kooperatif Think Pair Shere dengan bantuan tutor sebaya ketuntasan hasil belajar siswa kelas x yaitu $(18,18 \%)$ dari 33 orang siswa di MAN 2 pontianak semester genap.

2. Setelah menerapkan metode kooperatif Think Pair Shere dengan bantuan tutor sebaya ketuntasan hasil belajar siswa kelas x yaitu $(48,48 \%)$ pada siklus II dan ( 93,93 \% ) pada silkklus II dari jumlah siswa 33 di MAN 2 pontianak semester genap.

3. Sebelum menerapkan metode kooperatif Think Pair Shere dengan bantuan tutor sebaya termotivasi. karena dengan prestasi yang dicapai sesuai yang diharapkan (KKM) x yang berjumlah siswa 33 di MAN 2 pontianak semester genap.

Pendapat siswa setelah menerapkan metode kooperatif Think pair Shere dengan bantuan tutor sebaya antara lain :

1. Dengan adanya metode kooperatif TPS dengan bantuan tutor sebaya, saya lebih mudah memahami materi. merasa leluasa bertanya sama kawan sebaya, sehingga suasana belajar menjadi aktif, termotivasi untuk belajar secara berkesinambungan. saya yang sebelumnya pasif dengan adanya metode kooperatif Think Pair Shere dengan bantuan tutor sebaya menjadi lebih aktif dan suasana pembelajaran menjadi hidup.

2. Setalah diterapkan metode kooperatif Think Pair Shere dengan bantuan tutor sebaya, nilai ulangan banyak yang tuntas 
8 Jurnal Pendidikan Matematika dan IPA Vol. 5. No. 2. Juli 2013: 1-8

dibandingkan pada ulangan sebelum menerapkan metode kooperatif Think Pair Shere dengan bantuan tutor sebaya.

\section{Daftar Pustaka}

Arikunto, Suharsimi. 2010. Prosedur Penelitian Suatu Pendekatan Praktek. Jakarta: PT Asdi Mahasatya.

Anang Heriawan, Darmajari, Arif Senjaya, 2012, Metodelogi Pembelajaran kajian teoritis praktis, Serang Banten: perum Bumi Baros

Chasanah.

Daroeso, Bambang. 1986. Dasar dan Konsep Pendidikan Moral Pancasila. Semarang: Aneka Ilmu.

Ibrahim R, Syaodih S Nana, 2003. Perencanaan Pengajaran . Jakarta : Rineka Cipta.

Kemp, J,E., Morisson, G.R., and Ross, S.M. 1994. Designing Effective Instruction, New York : Macmillan College Publishing Company. 